\title{
Regionalization of violent jihadism and beyond: the case of Daesh
}

\author{
Ekaterina Stepanova
}

In the early $21^{\text {st }}$ century, violent extremism in general and Islamist violence in particular have been dominated by several jihadist movements that are regionally-based, primarily operate at regional level and have been undergoing the bottom-up regionalization process. All these movements are major combatants in the world's most intense regional armed conflicts and the lead terrorist actors against non-combatants. All try to build Islamic states in their regions. They are distinct from both peripheral Islamist/separatist insurgencies fought at subnational level and from al-Qaeda as an inherently extraterritorial movement and ideology, with a fully globalized agenda. Against this background, Daesh, or the "Islamic State", did not emerge as a global phenomenon, but as a regional movement in the Iraq-Syria context, driven by bottom-up regional dynamics and conflicts facilitated by collapse or weakness of states of the region, fueled by sectarianism and catalyzed by external interventions. The key question is: what turned this regional actor into the new cutting edge of "global jihad" as a movement and ideology? The article identifies three main trends in the evolution of transnational violent Islamism: bottom-up "regionalization", network fragmentation of the "global jihad" movement and the intensification of targeted intra- and cross-regional jihadist "migration flows". While interrelated, these trends are distinct, develop in parallel to one another, and only partially overlap. It is precisely where they overlap that the Daesh phenomenon has formed.

Ekaterina Stepanova heads Peace and Conflict Studies Unit at the Institute of the World Economy and International Relations, Moscow. She is a Russian Academy of Sciences Professor and lectures at the European University in Saint-Petersburg. She authored 170 publications in ten languages and several books, including Terrorism in Asymmetrical Conflict: Ideological and Structural Aspects (Oxford University Press, 2008). In 20072009, she directed Armed Conflicts and Conflict Management Program at Stockholm International Peace Research Institute.

\section{Introduction}

In the early $21^{\text {st }}$ century, the main challenge of violent Islamist extremism has been posed by neither Islamist/ethnoseparatist groups in peripheral low-intensity conflicts mainly fought at subnational level, nor by the fully globalized, extraterritorial fragmented network known as "al-Qaeda". Violent extremism in the $21^{\text {st }}$ century has been dominated by radical Islamist (jihadist) movements that are regionally-based and primarily operate at regional level. In this context, a "region" 
refers to a supra-national and transnational political and geographical space (e.g., the Horn of Africa, North Africa, Southeast Asia, Southwest Asia, Middle East ${ }^{1}$ etc.). For armed Islamist-jihadist actors active in these regional spaces, the degree of regionalization may fall anywhere between the systematic cross-border spillover (e.g., for Nigeria-based "Boko Haram") to acquiring a more thorough regional scale (as in case of the inherently cross-border "Islamic State", or Daesh, in the Iraq-Syria context and across the Middle East). This article's central focus on regionally-based Islamist-jihadist groups is merited by two facts.

First, more generally, they dominate among all other non-state militant-terrorist actors around the world, religious or secular alike, in terms of intensity of violence. Out of the top most active militant/insurgent-terrorist groups of the past decade, the majority - from seven to eight groups, depending on the particular year - were radical Islamist (Islamist-jihadist) movements. These included the Islamic State of Iraq and Levant/“ash-Sham" (ISIL/ISIS, or Daesh by its abbreviation in Arabic), the Taliban in Afghanistan, Tehrik-e-Taliban in Pakistan, "Boko Haram" in Nigeria, Somalia-based "ash-Shabaab", closely followed by Syria-based "Jabhat an-Nusrah", "al-Qaeda in the Arabian Peninsula", and "Lashkar-e-Jangvi" in Pakistan. These jihadist groups, especially the top five, remain the most lethal and it is this type of group that has driven global increases in intensity of armed violence by non-state actors. According to Global Terrorism Index, much of the terrorist activity in the world in 2014 has been concentrated in just five countries - all the main areas of origin and operation of cross-border, regionally-based violent Islamist groups from the list above: $78 \%$ of all deaths and $57 \%$ of all terrorist attacks occurred in Afghanistan, Iraq, Nigeria, Pakistan and Syria. ${ }^{2}$ In 2014, Daesh and Boko Haram alone were responsible for $51 \%$ of all claimed global terrorism fatalities. ${ }^{3}$

Second, more specifically, it is armed groups of the regional scale and mainly active at the regional level that dominate both in the above-given list and among all perpetrators of Islamist violence. On this count, a handful of major regionallybased jihadist movements leave far behind much more numerous and more widespread localized Islamist-separatists groups, on the one hand, and the waning al-Qaeda as an inherently extraterritorial movement and ideology, with a fully globalized agenda and no single core regional/territorial base, on the other hand. A November 2014 "snapshot" of the state of jihadist violence around the world that month showed that $80 \%$ of all fatalities of such violence were concentrated in just four countries - Iraq, Nigeria, Afghanistan, and Syria, with Iraq alone accounting for over a third of the total and Nigeria, Afghanistan and Syria each

1 In this usage, the Middle East includes the Arabian peninsula, Cyprus, Egypt, Iraq, Iran, Israel, Jordan, Lebanon, Palestinian territories, Syria, and Turkey.

2 See Global Terrorism Index 2015: Measuring and Understanding the Impact of Terrorism (Sydney: Institute for Economics and Peace, 2015), p. 2.

3 See ibid. p. 14. 
responsible for $13-15 \% .{ }^{4}$ In all these areas, the lead perpetrators of such violence are both $(a)$ explicitly jihadist and $(b)$ regionally-based, regionally-active and primarily regionally-focused movements.

All these movements are the main and major combatants in respective regional armed conflicts. All, in addition to combat, employ terrorism against civilians and non-combatants - more actively than most other militant groups across the world. All call for and try to build Islamic states in their respective regions. All systematically engage in cross-border violence and display various degree of regionalization of armed/terrorist activity.

The following sections explore the dominant "bottom-up" type of regionalization of violent radical Islamism in the early $21^{\text {st }}$ century, analyze the Daesh phenomenon in the Iraq-Syria context through the prism of its regional roots and regionalization process, highlight the specifics of Daesh as compared to both other regionalized violent Islamist movements and to al-Qaeda, and explain transnationalization of Daesh beyond its region.

\section{Jihadism and violent Islamist extremism: definitional aspects}

Before turning to the subject matter, two important reservations need to be made.

First, not any ethno-confessional insurgency fought by Muslims in a Muslim or Muslim-minority country against national government or/and foreign forces can be deemed a "jihadist insurgency". Nor even any broader armed movement driven by hybrid ideology that fully integrates the Islamist imperative and combines religious and nationalist, or national liberation, elements qualifies. In fact, neither most Muslim/ethnoseparatist insurgencies fighting on the periphery of predominantly non-Muslim or multiconfessional states (a relatively standard case, e.g., for much of Asia and Eurasia where almost every second country faces this problem), nor such major Islamist/national-liberation movements fighting occupation as the Palestinian Hamas qualify as "jihadist". To qualify for a "jihadist insurgency", an armed group or movement should not only be guided by an explicit and dominant religious Islamist imperative, but also prioritize jihad by violent means over other tasks, in an inherently cross-border, transnational context.

Second, while the central subject of this article is violent religious extremism, it is never hurts to stress that our focus is not on religion, but on the synthesis of religion and ideology, understood and treated as a political category. This approach tries to avoid two extremes: $(a)$ sharp juxtaposition of ideology (as distinctly political category) and religion (as spiritual, cultural and ethical category) ${ }^{5}$ (b) the Weberian understanding of religion as ideology, interpreted as an ethical

4 Cf. Neumann 2015b, p. 13.

5 See, e.g., Williams 1996, pp. 368-378. 
system guiding people's behavior. ${ }^{6}$ This article does not treat "Islam" as ideology. Instead, it addresses a synthesis of religion and ideology in the form of highly politicized religious/ideological currents, such as Salafist jihadism, as practiced by most of the above-mentioned violent Islamist groups. In line with the French, Russian and most other continental European schools of orientalist and Islamic studies - and in contrast to the Anglo-Saxon tradition that normally does not distinguish between Islamic fundamentalists and Islamists - there is also a distinction made here between religious fundamentalism (that may not necessarily imply interest in politics and may prioritize theological, religious and ethical issues) and Islamism and the Islamist ideology (as ideology of political active and resurgent Islamic fundamentalism). Islamism itself is dominated by legalist sociopolitical-religious movements that oppose existing order, but may be ready to work within the system, principally in their own states, in order to change it (e.g., the majority of the "Muslim Brotherhood" branches). Of the wide range of groups and currents associated with the more radical Islamism, only few resort to armed violence, even fewer resort to indiscriminate violence against civilians, and even fewer prioritise violence over social, missionary or political activities. The focus of this piece is just on that latter segment.

\section{Regionalization: from top-down to bottom-up}

\subsection{Top-down regionalization?}

"Regionalization" has been the mainstream trend in transnational violent Islamism for years. However, in the early $21^{\text {st }}$ century the term was most commonly used to refer to a top-down process of the al-Qaeda evolution in the early $21^{\text {st }}$ century. The approach that described al-Qaeda's evolution primarily as the process of top-down regionalization gradually replaced the "al-Qaedaization" approach of the first post-9/11 years (that tended to see al-Qaeda almost everywhere, behind any act of Islamist terrorism and militancy in any regional context). ${ }^{7}$ The "regionalization" approach that had prevailed in the mainstream US and Western academic and security analysis by the 2010s, still left some direct strategic and command role for the "al-Qaeda core", or "al-Qaeda Central", leadership based in Pakistan and Afghanistan, but acknowledged its relatively declining role. It argued that the main level of al-Qaeda-affiliated and al-Qaedainspired militant activity had been shifting from the "al-Qaeda core" towards several relatively large, well-structured and organizationally coherent "regional affiliates" based and primarily active in Muslim region: al-Qaeda in the Arabian

6 Cf. Weber 1993, id. 2005.

7 Cf. Gunaratna 2002. 
peninsula, al-Qaeda in the Lands of the Islamic Maghreb, al-Qaeda in Iraq, alQaeda in East Africa etc. ${ }^{8}$

On the one hand, at the time this shift of focus was a certain step forward from primitive "al-Qaedaization" and was at least an effort to distinguish al-Qaeda "regional affiliates" from $(a)$ other genuine militant Islamist groups (such as Hamas or Hizbullah) that have become gradually integrated into respective national political contexts and $(b)$ from multiple localized "peripheral" Islamistseparatist insurgencies across the world. The "top-down regionalization" approach also left some place for the so-called al-Qaeda's "ideological adherents" small cells and individual adepts, including in the West people, "who know the group only through its ideology to carry out violence in its name", but interpreted this as a sign of al-Qaeda's weakness and organizational degradation explained primarily as a direct result of counterterrorist pressure from the United States and its allies. ${ }^{9}$

On the other hand, this search for relatively well-structured, organizationally and regionally coherent "heirs" to the waning al-Qaeda, to an extent, reflected a failure to grasp al-Qaeda's key strength and the main direction of its evolution and adaptation. Instead of investing in organizational development, al-Qaeda's ideological and strategic leadership emphasized and invested into the spread of the "global jihad" ideology, leaving the structural, politico-military and tactical forms and specifics to contextual conditions. Not surprisingly, the extent to which all organizations referred to and designated as Al-Qaeda "regional affiliates" by governments and security analysts actually qualified as such, and their role as alQaeda's direct and main successors could and have been disputed. One possible exception has been the Yemen-based "al-Qaeda in the Arabian peninsula" (AQAP). Of all the so-called al-Qaeda "regional affiliates", AQAP is the only one that both had a direct historical/genetic connection to the "al-Qaeda core" through Yemeni and Saudi-based radical clerics and veteran-jihadists and posed a serious threat beyond its region (e.g., in the form of pro-active ideological indoctrination of adepts, notably in the United States, by the radical preachers such as AQAP-affiliated Anwar al-Awlaki and its English-language jihadist journal "Inspire").

Most other so-called al-Qaeda's regional affiliates, be it in Iraq, Maghreb, the Horn of Africa or Southeast Asia, were more the products of bottom-up regional dynamics, than vehicles for the al-Qaeda decentralization. They all had strong and deep roots in their respective regional, historical and political contexts, sometimes activated by external interventions (as in the case of Iraq) or aggravated by them (as in Somalia or Libya), and emerged as largely authentic movements. Their real agenda had been and remained inextricably tied to respective regional/local

8 Cf. Rollins et al. 2011a; Rollins 2001b.

9 See National Strategy for Counterterrorism (Washington D.C.: The White House, 2011), pp. 3, 19; cf. Rollins et al. 2011a, p. 30. 
conflicts and issues. Their declared links or pledges of allegiance to al-Qaeda have been declarations of symbolic "loyalty" in support of shared ideological-religious goals. In most cases, no solid or verifiable evidence has been provided to prove any substantive operational, planning, logistical, financial or other direct links. ${ }^{10}$

A reference to al-Qaeda in the name of "al-Qaeda in Iraq" (AQI), quickly dropped by the group following the death of its first leader Abu Musab az-Zarkawi in 2006, did not reflect its real mission and raison d'etre. The main goal of this most radical, Salafist-jihadist part (and increasingly the core) of the Sunni resistance to US-led occupation of Iraq since 2003 and its proxy Shia-dominated government, had been replacing a Western protectorate in Iraq with an Islamist state. The absolute majority of its fighters and commanders had been comprised by Iraqis. While, in contrast to AQI in Iraq or "ash-Shabaab" in Somalia, "AlQaeda in the Lands of the Islamic Maghreb" (AQIM) has not been specifically tied to any single armed conflict and clearly aimed at a regional level, it was itself a revised edition of the Algerian Salafi Group for Call and Combat that in 1998 had split from Groupe Islamique Armé - the main rebel force in the Algerian civil war. Despite the AQIM's 2006 pledge of loyalty to al-Qaeda, even the US government sources described the character of links as "nominal", stating that "the group does not appear to take directions from leaders in Afghanistan/Pakistan". ${ }^{11}$ Some radical Islamist networks in more distant regions, such as "Jemaah Islamiyya" in Southeast Asia, had either evolved for decades well before al-Qaeda or developed in parallel to, rather than in coordination with, the latter, or both. Even the latest case of "Jabhat an-Nusrah" in Syria that, after its formal recognition by al-Qaeda religious-ideological leader Ayman az-Zawahiri in 2013, become widely known as al-Qaeda's "branch", or "affiliate", is quite ambiguous. This Salafist-jihadist group emerged in late 2011 in the course and context of the Syrian civil war (at first as a Syrian off-shoot of "Islamic State in Iraq") and has since remained largely confined to that context. ${ }^{12}$ The presence of foreign fighters in its ranks (second in size only to Daesh) notwithstanding, "an-Nusrah" has been dominated by Syrians and is far more "Syrian" than its main rival - the cross-border "The Islamic State", or Daesh. ${ }^{13}$ In practice, neither the degree of "an-Nusrah's" support from foreign sources, including some regional states, nor its call for building an Islamic sharia-based state in Syria and its imposition of sharia-based order in areas under its control do not differ from the agenda and the way other relatively large armed Islamist groups (such as "Jeish ul-Islam" or "Akhrar ash-Sham") operate in Syria. "An-Nusrah's" continuing interest in the "al-Qaeda" brand and

10 Rollins 2001b, p. 5.

11 Rollins et al. 2011a, p. 19.

12 See "Jabhat al-Nusra", in: The Mapping Militants project, Stanford University.

13 As of September 2014, 19 out of the Daesh top 20 leaders were from Iraq, while only one was Syrian. See: "Who are ISIS's top 20 leaders?", in: Al-Arabiya, 19 September 2014. 
blessing could be partly explained by the need to counterbalance, in ideological terms, its powerful and prevailing rival, Daesh.

\subsection{Bottom-up regionalization}

Regardless of how accurately the top-down regionalization scheme applied to evolution of al-Qaeda, most major jihadist actors in the $21^{\text {st }}$ century have, indeed, been regionalizing. These processes, however, largely followed the opposite pattern of bottom-up regionalization. In addition to the Daesh phenomenon in Iraq and Syria as a show-case of such bottom-up regionalization in the broader Middle Eastern context, this tendency has also fully manifested itself in the evolution of several jihadist movements in regions beyond the Arab Middle East, ranging from East/West Africa to South and Southeast Asia. This is as true for "ash-Shabaab" or "Boko Haram" as it is for the Taliban across the AfghanPakistani border, even as the variety of contextual conditions and specifics is immense.

As noted above, even for most of those groups that had at some point declared formal loyalty to al-Qaeda, bottom-up tendencies and regional dynamics prevailed over top-down decentralization impulses. Nowhere did the bottom-up shift from a more localized to a more regionalized movement manifest itself better than in the case of the jihadist "ash-Shabaab" movement in Somalia. In a protracted and highly fragmented armed conflict in Somalia, a sequence of dysfunctional "transitional governments" supported mostly by neighboring states and by "the international community" had for decades been confronted by Islamist rebels. In 2006, the lead Islamist organization, the Islamic Courts Union, with support from corporations of local traders, finally succeeded in establishing a more stable control in the capital Mogadishu. It is only after this functional and more moderate Islamist regime was forced out of power by the Ethiopian military intervention undertaken with the US covert support that the lead role in the resistance shifted to the more radical splinter "ash-Shabaab" ("youth") jihadist movement. "Ash-Shabaab" strictly imposed sharia in areas under its control in southern Somalia. ${ }^{14}$ While its targets have been primarily confined to Somalia (where it mostly attacks the government, the Ethiopian military and the African Union peace enforcement presence), since 2010, "ash-Shabaab" expanded its activity to terrorist attacks in the neighboring states (Uganda, Burundi) that it wanted to withdraw their forces from Somalia. As a long-term goal, "as-Shabaab" aims at building an Islamic state in the Horn of Africa. It was not before the 2011 Kenyan intervention in southern Somalia, however, that "ash-Shabaab's" leader pledged loyalty to the already globally waning al-Qaeda in 2012.

\footnotetext{
14 For more details, see Marchal 2011.
} 
Another major African case in point is that of "Boko Haram" that has evolved in northeastern Nigeria since the mid-2000s. The movement did not start as a violent one and only turned to militancy and terrorism in 2009-2010, operates in a relatively peripheral Muslim region, as compared to the Middle East, and has limited transnational appeal. Nevertheless, Boko Haram overtook Daesh as the most deadly terrorist group in the world in 2014. While Boko Haram accounted for 6644 terrorist fatalities in 2014 (77\% of whom were private citizens), Daesh was responsible for 6073 (with private citizens comprising $44 \%$ ). ${ }^{15}$ As of the mid2010s, Boko Haram is not only more heavily oriented towards terrorist activity against civilians and all non-combatants than Daesh or the Afghan Taliban, but also displayed the most radical increase in terrorist activity. While this large movement is strongly rooted in Nigerian socio-political context and operates primarily at the national level, it is increasingly a networked and cross-border phenomenon, has been gaining a higher international profile, mostly by demonstrative acts of violence, and has a major regional potential. ${ }^{16}$

Compared to these more recent cases, the cross-border Taliban movement has been a long-standing phenomenon. The movement's emergence and evolution was overwhelmingly rooted in and driven by contextually specific factors and conditions, ranging from the dynamics of the intra-Afghan conflict since the early 1990s to support from Pakistan. The Taliban de facto government's readiness to host Bin Laden as a "paid guest" since 1996 notwithstanding, the movement has always been strictly confined to its own region and, even more narrowly, to the Afghanistan-Pakistan context. After the Taliban government (1996-2001) was forced out by the US-led intervention in Afghanistan, and throughout the gradually reemerging and escalating Taliban insurgency against the US and NATO forces and the Afghan government in the early $21^{\text {st }}$ century, the loyalty of various parts of this hardly monolithic movement on either side of the border remained firmly to its own charismatic Quetta-based leader Mullah Omar. The factors that confined the Taliban strictly to the Afghanistan-Pakistan context included, but were not limited to, increasingly cross-ethnic, but still heavily Pashtu-dominated nature of the movement (that emerged as a mix of Islamism and Pashtu nationalism), the non-Salafist character of the Taliban religious fundamentalism (of the Deobandi version of the Hanafi school that prevails in Afghanistan), and Pakistan's determination to instrumentalize the movement for its regional goals (such as increasing Islamabad's leverage in Afghanistan, notably vis-a-vis India, shifting the gravity center of the Pashtu issue from Pakistan to Afghanistan etc.). ${ }^{17}$ Neither the new military advances by the Afghan Taliban since 2014, nor even its split, following the confirmation of Mullah Omar's death, could change the movement's central focus on the armed conflict in Afghanistan and on sharia-based

15 See Global Terrorism Index 2015, p. 14.

16 See De Montclos 2014b; id. 2014a.

17 For a balanced account on the Taliban evolution, see, e.g., Rubin 2015. 
governance in areas under its control. Since 2015, the mainstream Taliban faction even got in conflict with the more ambitious, but not endemic and less locally rooted "Vilayat Khorasan" project involving Daesh(-inspired) militants in Afghanistan and Pakistan. ${ }^{18}$

As it could be seen from above, cross-border, regionally based Islamist insurgencies with state-building ambitions could be traced in various regions beyond the Arab Middle East. However, this only tends to become an issue of major international security concern in regional contexts marred by a combination of chronic state weakness or failure, protracted major conflicts and all-out civil wars and high degree of transnationalization, including covert state support, or even formal internationalization (foreign military presence). It is in these conditions that the bottom-up regionalization of a radical Islamist movement leads to multiplication and qualitative upgrade rather than erosive fragmentation and decline of its military-political potential and militant/terrorist activity.

Of all regionally based and regionalizing violent Islamist movements, the Islamic State of Iraq and Levant, or Daesh, has not only been the most explicitly "jihadist", but also the only one with ideological ambitions extending beyond the Iraq-Syria context and the Middle East at large. Even so, the formation and evolution of Daesh is also a major show-case of bottom-up regionalization, not a case of top-down breakaway protrusion or natural progression from al-Qaeda. The special focus on Daesh in this article is merited by its dual character as both $(a)$ an epitome case of bottom-up regionalization and $(b)$ a cutting edge of mobilization and transformation of transnational violent jihadism and its main current center of gravity, as of the mid-2010s.

\section{Daesh as a case of bottom-up regionalization}

In fact, no other major regionalizing Islamist movement has been so strongly driven by factors internal to the countries (Iraq and Syria) and the region in question (the Middle East) as Daesh has, even as some of these dynamics were initially set in motion or catalyzed by the external intervention in Iraq in 2003. Regionalization of a civil war in Syria has also largely, although not exclusively, been a product of intra-regional dynamics. Acting in two (semi)failed state contexts - in Iraq as a chronically failing post-intervention state and in Syria seriously weakened by a heavily transnationalized civil war - Daesh provides an even more impressive example of a regional militant-terrorist movement with a powerful

18 "Vilayat Khorasan" (the "Islamic" name for both Afghanistan and Pakistan) is the first formally recognized Daesh "branch" outside the Arab world, officially announced by Daesh on 26 January 2015. While the scale of its presence in Afghanistan is hyped, it has been in conflict with the mainstream part of the Taliban insurgency, while attracting some ex-Taliban fighters and splinter elements. See, e. g., Ruttig 2015. 
ideology, major state-building ambitions and quasi-state potential than the crossborder activity and phenomenon of the Taliban in the Afghanistan-Pakistan context. The bottom-up regionalization process that led to the rise of Daesh in the Iraq-Syria context manifested itself in terms of the main driving factors for the Daesh evolution, the main area and level of its most direct and strongest impact and implications, and also at the ideological-religious level.

The factors and dynamics most relevant to emergence and regionalization of Daesh may be grouped at two levels: micro-regional (national) and macro-regional. The process started (in Iraq) and has been ongoing at the micro-regional level (in Iraq and Syria) since the mid-2000s and remains firmly rooted in and primarily based at that level. The ongoing bottom-up regionalization of Daesh was, however, qualitatively upgraded and amplified by dramatic processes at the macro-regional level that merged together in the early 2010s to produce a systemic regional crisis in the Middle East and itself became a major manifestation of that region-wide crisis.

\subsection{Micro-regional level}

The so-called Islamic State, or Daesh, originated in the early $21^{\text {st }}$ century in postintervention Iraq which has remained its main center of gravity through the mid2010s and where it has acquired and kept a lasting support base among Sunni Arabs. The two main Iraq-based roots of Daesh were the total collapse of the Iraqi state as a result of the US-led 2003 intervention and the ensuing rise of sectarian dynamics that quickly filled the vacuum in the form of the Shia-centric state building and growing Sunni estrangement from and opposition to that project. This refers to widespread, genuine grievances and discontent by various groups of Iraqi Sunnis ranging from the former Baathists to tribal groups to Islamists with their growing political and socio-economic marginalization and repression in Iraq since 2003. Resentment of the Iraqi Sunni Arabs toward the increasingly Shiacentered "dysfunctional order" in post-2003 Iraq took different forms ranging from reluctant acceptance/neutrality to armed violence, including in extreme forms. However, it also gradually radicalized both in its non-violent part and inside the Iraqi Sunni initially very fragmented insurgency. Ultimately, this led to increasing consolidation of the most determined and militarily capable part of the Sunni resistance in Iraq around a Salafist-jihadist agenda and movement embodied by the "Islamic State in Iraq" (ISI) group, previously known as "al-Qaeda in Iraq".

This discontent and radicalization helped feed the anti-U.S. insurgency, continued to accumulate during the rule of the unpopular Iraqi regime of Nuri alMaliki (2006-2014) inherited from the foreign security presence and characterized by growing authoritarian tendencies, limited functionality and low legitimacy, and did not abide under the successor government of Haider al-Abadi 
(since September 2014). The growth of Daesh and its major advances in Iraq became the most extreme form of this longer and broader phenomenon of the Sunni rejection that played a central role in its emergence and remained a major factor in its evolution. The capture of Mosul by the Islamic State in June 2014 cannot be understood outside the decade-long series of the battles and atrocities in Fallujah, the rise and radicalization of the Iraqi insurgency in 2006-2007 and the broader Sunni protest movement of the early 2010s. ${ }^{19}$

The escalating and increasingly sectarian civil war in the neighboring Syria since 2011 further alienated most Syrian Sunnis from the minority rule Asad regime and radicalized many followers of the more moderate Islamist movements, such as the Muslim Brotherhood, to form or join a range of more radical, jihadist groups. While the latter started to be beefed up, both for ideological reasons and as the most efficient anti-government fighters, by anti-Asad regional powers (notably Saudi Arabia and Qatar), the central government turned to support from Shia actors across the region ranging from Iran to Lebanese Hizbullah. The rapid sectarianization and regionalization of the internal conflict in Syria, amidst its multiple other internal socio-political fault lines, growing complexity and fragmentation of violence, and the narrowing space of governance provided an ideal opportunity for the "Islamic State in Iraq" to expand across the border, secure a haven, build a second country-base in Syria, enhance its financial base by getting control of the cross-border smuggling of oil and to upgrade itself, first, to a regional movement of "Iraq and Levant" and, next, to a reincarnation of the Islamic Caliphate in part of its historical lands.

The worst thing about sectarianism in Iraq (and Syria) - is that it become a selfperpetuating cycle: suppression of (part of) a large sub-national community fueled radicalization and increasingly sectarian response (with Daesh as its most extreme and violent form), which was then often countered by means that contributed to reproducing and even reinforcing the conditions that gave rise to the Islamic State in the first place. For instance, from an Iraqi Sunni point of view, the government-sanctioned "Hashd al-Shaabi" (the mass mobilization of volunteers and old and new Shia militias to repel the Islamic State, following the fatwa call by Grand Ayatollah Ali al-Sistani in June 2014) has become "the most serious defense of Shia-centric state building" and as much an expression of the rise of sectarianism in Iraq as the Islamic State itself. ${ }^{20}$

However, it would be inaccurate to reduce Daesh in Iraq and/or Syria to both a product and a reproducer of sectarianism alone. Its ultra-sectarian character should be analyzed along with a combination of at least three other key characteristics. On the one hand, they include (1) extreme religious fundamentalism that totally rejects anything secular, including the very idea of the Iraqi (Syrian or any other) nation-state and merges with (2) extreme violence that goes beyond more

19 For more details, see Haddad 2016; Mansour 2016; Haddad 2011.

20 Haddad Fanar 2016, p. 1. 
regular combat or even terrorism as standard tactics of many militant insurgent/ terrorist groups and acquires a genocidal/cleansing dimension (especially against the Shias and other Muslim "apostates"). On the other hand, the Daesh phenomenon in Iraq (and in Syria) itself embodies (3) a reaction to protracted conflict, routinization of violence, chaos, collapsed or fragmented order. This reaction took the form of religious/ideologically-based efforts to establish "alternative" basic governance, impose Islamist sharia-based law and order, start partial reconstruction of infrastructure (beyond oil production and gas processing to include water supply pipelines) and provide minimal social welfare. ${ }^{21}$ For Daesh, this latter pillar has not merely been a means to survive and function as an efficient military actor in order to gain more territorial and population control through fighting (jihad), but underscores the movement's central ideological, religious and politico-military focus on building a region-based "Caliphate" extending "from Aleppo to Diyala"22 as the center of "true" Islamic order and governance and a destination for hijrah (emigration) for Muslims from elsewhere.

\subsection{Macro-regional level}

In the 2010s, "Islamic State in Iraq" did not simply mechanically expand to a crossborder "grey area" haven in the neighboring Syria as another failing state mired in a major civil war. The movement's evolution and further regionalization was qualitatively amplified by - and became an integral part of and, to an extent, hostage to - the broader socio-political processes at the macro-regional level.

Parts of the Middle East have been areas of instability, particularly traumatic and painful modernization, deep social problems and continuing and new armed conflicts throughout the early $21^{\text {st }}$ century. However, in the early 2010 s the Middle East entered a full-scale systemic crisis that affected states and societies and permeated politics, any definition and aspect of security, and social economy across the region. Its main manifestations included major and nearly simultaneous social (socio-political) upheavals that became known collectively as the "Arab spring"; the fundamental crisis of many existing states, especially of the republican regimes; the ever intensifying transnationalization of most social processes, including social protest, political/religious violence and extremism; growing tensions and increasing competition for influence among key regional powers and the accelerating erosion of, and shift in, regional balances of power.

21 For a detailed overview, see: "The Islamic State (IS) Establishes Itself In Iraq And Syria", in: The Middle East Media Research Institute (MEMRI), Inquiry \& Analysis Series Report no. 1126, 22 October 2014.

22 Declaration of the reestablishment of the "Caliphate" by ISIS spokesman: Abu Muhammad al-Adnani al-Shami, "This is the Promise of Allah", Al-I'tisam Media Foundation Twitter account, 29 June 2014 (account suspended by Twitter). 
Elements of these trends could be traced here and there and accumulated in the region for decades. However, in the 2010s they burst simultaneously and merged together to produce a new quality. The overall crisis in regional security, regionwide instability, a wave of internal upheavals and/or heavily transnationalized and internationalized civil wars, and intractable regional rivalries reached a scale and intensity that neared the prospects of region-wide destabilization and disintegration of several states at once (Libya, Iraq, Syria, and Yemen). In all of them, violent extremism of the most radical Islamist type, transnationalized to varying degree, has emerged as the worst manifestation of such systemic crisis and a major challenge to state and society. This extreme Islamist militancy in the form of cross-border and more broadly transnationalized movements should be seen more as a product and manifestation of these broader, underlying processes and shifts rather than as the cause. However, once firmly taking root, this type of violent extremist actor - most clearly embodied by ISIS/Daesh - itself became a powerful driver and catalyst of the overall systemic crisis - both as a generator of armed violence, including extreme violence against civilians, and as an active challenger of the regional order and alternative quasi-state-builder.

The "Arab Spring" as a major catalyst and manifestation of the region-wide systemic crisis not only helped set in motion one of the two main country-specific contexts for the evolution of Daesh - the rise of social, initially more pro-democracy than fundamentalist protest in Syria followed by rigid counter-reaction by the Asad government and turning into anti-government violence whose secular component gradually degraded to give way to the more and more radical violent Islamism of the increasingly sectarian and jihadist bent. More broadly, the violent extremist/quasi-state Daesh phenomenon has been as much an integral part and manifestation of the systemic crisis in the Middle East as the sociopolitical phenomenon of the "Arab Spring". Furthermore, at the macro-regional level, Daesh may also be seen as a non-system (counter-)reaction to the "Arab Spring" and especially to the role played in the latter by reformist Islamist movements. In terms of ideology and methods employed to challenge the system, the emergence of Daesh could be described as the opposite end of the pendulum swing, as reinstating the need for "change through jihad" in reaction to the culmination of "change through reform/peace" in "Muslim Brotherhood" taking power democratically in Egypt. Daesh emerged as an assertive rival of "the Arab spring" that was (a) hyperconservative in ideological outlook, $(b)$ extremely violent and ferocious in its methods; but at the same time $(c)$ highly competitive with the "Arab Spring" actors in mastering the communication, outreach and mobilization advantages of the digital age. ${ }^{23}$

23 For more details on the Daesh information and communication strategy and tools, see Atwan 2015. 


\subsection{Impact and solutions within the region}

In terms of the overall impact, the gravest and most direct implications of the Daesh activity once it has taken its full shape affect, first and foremost, the region itself. It is within its region, that had already been the world's main center of terrorist and militant activity for much of the early $21^{\text {st }}$ century, that the Daesh military advanced coupled with a major quasi-state experiment threatened to deal a massive, if not necessarily final, blow to two already failing or seriously weakened states at once and thus to add a new quality to the broader regional destabilization. It is within the region, primarily in the two countries in point, that the impact of the Daesh violence, including against civilians, has been concentrated.

The Daesh marked, extreme radicalism and brutality of its methods also stem not just from the extreme fundamentalism of its religious ideology that claims literal return to the tough times of the early Islam, but from contemporary regional dynamics and can be partly explained at the regional level. For instance, Daesh's extremely harsh position on the excommunication of all Shia and other "apostates" and meticulous implementation of this policy in practice continue from and could be tracked back to its experience in Iraq's war and from the marked sectarianism of its ISI/AQI. This was aggravated by the Daesh involvement in the increasingly sectarian Syrian conflict that, in view of growing meddling by the Gulf states, on the one hand, and the covert involvement of Iran and the Lebanese-based Hizbullah, was also increasingly becoming part of the regionwide sectarian tensions. Not surprisingly, so far, the bulk of victims of individual and mass killings on the Daesh-controlled territory have been Muslim "apostates". Daesh's hyper-sectarianism overlaps with, builds upon and itself promotes region-wide sectarian Sunni-Shia divisions and violence (further reignited, at the inter-state level, by the new Saudi-Iranian rift of the early 2016). As mentioned above, in ideological-religious terms, the extreme rigidity of Daesh and its selfupgrade to "the Islamic Caliphate" was the most radical counterreaction to the driving forces and political-ideological impulses behind the "Arab spring" perceived by extreme Salafist jihadists as a "trait" by Muslim apostates. For them, that massive "trait" actualized the need for direct pursuit of Caliphate through ever more rigorous and brutal jihad, literally reproducing norms of war of the times of the early Islam.

The major implication of understanding the regional roots, base and the bottom-up regionalization of Daesh is that efforts to weaken it militarily from the outside may diminish its territorial control, cut its financial base and reduce the inflows of foreign fighters, ${ }^{24}$ but could not remove the deeply entrenched factors at national/micro-regional level that gave rise to this phenomenon in the first place

24 According to Pentagon, in April 2016 the flow of foreign fighters into Iraq and Syria has dropped over the past year from roughly 2000 down to 200 a month. See Gibbons-Neff 2016. 
or macro-regional dynamics that facilitated its further regionalization. Addressing the Daesh challenge at the broader international/global level would not solve the issue of sectarianism in Iraq or Syria, nor that of the legitimacy of the Iraqi (and Syrian) state. This task requires some form of a regional compact and, above all, country-based/national solutions (power-sharing, more pluralistic systems balancing between state functionality and decentralization). These could result from long, internationally mediated negotiation process, as in the Syria case, or, perhaps, even from some new major social upheaval (as suggested by the storming of Iraqi parliament on 30 April 2016 by supporters of Iraq's only relatively massbased social movement led by Ayatollah Muqtada as-Sadr, the only Iraq Shia leader with at least some potential of broader cross-sectarian appeal).

\section{Daesh and al-Qaeda}

Much of the debate on the Daesh ideology not only neglected and de-emphasized the movement's deep regional roots, but also, with rare notable exceptions, ${ }^{25}$ has been practically hijacked by the focus on differences, competition and outbidding between Daesh and al-Qaeda at the "global jihad" level.

Indeed, there are some important ideological and practical nuances between the two.

- In contrast to al-Qaeda and its followers, Daesh does not see "Islamic Caliphate" as an abstract, distant, extraterritorial and utopian end-goal. Instead, it has been building a physical, territorially-based Islamist Caliphate here and now, in its own region. For Daesh, establishing and consolidating "Caliphate" as a state emulating the early Islamic model comes as a more important and more urgent priority than even the "global jihad", including against the West. ${ }^{26}$ Even as Daesh issued a call for attacks in the West on 22 September $2014,{ }^{27}$ the movement's primary focus firmly remains on the areas and the region where the "Caliphate" is being built.

- Both the Daesh version of the Caliphate and its general appeal are considerably more populist and grass-root, at least in its own sectarian context - a sort of "people's Caliphate" for disenchanted (Sunni) Muslims, as opposed to original al-Qaeda's relatively elitist message and structure based on Sayyed Qutb's vision of elitist Islamist vanguard cells purifying themselves of the "ocean" of ignorant and materialistic "masses". ${ }^{28}$ In some way, this part of the Daesh

25 See Haykel 2015; see also prof. Bernard Haykel quoted in: Wood 2015; Carmon et al. 2014.

26 As stated in Daesh's journal in English "Dabiq": "The Islamic State [comes] before al-malhama [the battle against the Crusaders]." (Dabiq, no. 3, p. 5.)

27 Abu Muhammad al-Adnani 2014.

28 See Qutb 1980, pp. 12, 20, 47, 79-80. 
phenomenon could even be seen as a continuation, in a different context, of the line in transnational jihadist movement that had been earlier embodied by Abdullah Azzam (a major ideologue and practitioner of "armed jihad" who had fought against the Soviets in Afghanistan). While having had reinterpreted "armed jihad" as "an individual duty of all Muslims" (rather than a collective duty that could be delegated to someone else), Azzam had also emphasized mass armed resistance "in defence of Muslim lands" and a more populist agenda. ${ }^{29}$ This line stood in certain contrast to that of Osama bin Laden - an elitist, globally-oriented financial mediator and coordinator of jihad in Afghanistan who, following the death of the more popular Azzam in 1989, inherited and led the left-over transnational jihadist networks and turned them into what later became al-Qaeda.

- While universalist extraterritorial al-Qaeda emphasized the importance of doctrine in its ideology and rhetoric, territorially based Daesh has prioritized harsh enforcement and implementation of rigid interpretation of Islamic law through its governance and social policies and practices.

Sporadic political-military tensions between the two currents could be seen, from time to time, on the ground in the Iraq-Syria context, including in the form of violent clashes between Daesh and al-Qaeda-affiliated "Jabhat an-Nusrah". Also, like waves, these rifts in some form projected themselves into other, more distant conflict areas, catalyzing new splits among local/regional violent Islamists (in places ranging from the Afghanistan-Pakistan context ${ }^{30}$ to Russia's North Caucasus $^{31}$ ). However, in practical terms, these nuances should not be overestimated. Even in the Iraq-Syria context, operational fighting alliances between groups loyal to al-Qaeda and Daesh have not been infrequent on the ground; jihadist groups also at times cooperated and coordinated their activities in other ways (including by establishing joint sharia courts).

More generally, however, when it comes to trying to explain the Daesh phenomenon, the "Daesh vs al-Qaeda" angle appears to be the wrong way to start, in the first place. The explanation of Daesh has to start at the regional level (see previous section), not with how it competes with al-Qaeda for primacy in "global jihad". The nuances between the two are certainly important - but they are more of an outcome than substance of the process of the Daesh evolution from bottomup regionalization to the broader transnationalization beyond the Iraq-Syria context.

While Daesh epitomizes the bottom-up regionalization pattern, that pattern, as noted above, also characterizes several other major radical Islamist groups in different regions. Daesh, however, stands out even among all other most active

29 See Azzam 2002.

30 See McFate / Denaburg / Forrest 2015; see also note 13.

31 See Stepanova 2015. 
and violent territorially-based violent Islamist movements on a number of counts. All of such regional or regionalizing movements have also managed, to varying extent, to establish a solid financial basis, run basic governance and even engage in more ambitious state-building experiments. Daesh, however, not only built an army that has been one of the main combatants in the world's two most intense armed conflicts simultaneously and, at its peak, displayed the capacity to conduct offensive military operations in two different theaters at once (having captured Ramadi in Iraq's Anbar province and Palmyra in Syria in May 2015). It also claimed direct pursuit and legacy of a revived "Islamic caliphate" at part of its "historical lands", has most persistently put it into life in practice, at the military, administrative, social and other levels and attracted the largest inflow of foreign fighters since the conflict in Afghanistan in the 1980s (see the next section).

In sum, Daesh is a category of its own. On the one hand, it differs from other regionally-based violent Islamist movements by its claim for supreme legitimacy and broader transnational appeal - to the point of becoming, in the mid-2010s, the cutting edge of the "global jihad" movement, or, using al-Baghdadi's own words, "the spearhead" in "the war of every Muslim in every place", "the war of the people of faith against the people of disbelief". ${ }^{32}$ On the other hand, Daesh is in several important respects distinct, in both ideology and practice, from the most globalized, extraterritorial al-Qaeda-centered movement. However, over-emphasizing differences and competition between Daesh and al-Qaeda at the transnational level may distract attention from a more important question.

Daesh did not emerge as a global phenomenon. Much like other regionallybased violent Islamist groups, Daesh originally emerged as a regional movement, driven by regional dynamics, regional conflicts (including those unleashed by external interventions), gravely facilitated by and further undermining collapse or weakness of states of the region, fueled by and itself further fueling regional sectarianism. The key question is: what turned this regionally-based movement into the new cutting edge of "global jihad" as a movement and ideology?

\section{Explaining transnationalization of Daesh beyond the region}

Considering the ideological, religious and symbolic centrality of the Arab Middle East for the ideology and practice of transnational Salafist jihadism, the Daesh phenomenon simply could not stay confined to Levant, nor even to the broader Middle East. Earlier, at the turn of the century, the 9/11 attacks in the United States that had put al-Qaeda in the global limelight were the first anti-system

32 "March Forth Whether Light or Heavy", Transcript of an audio speech by Abu Bakr Al-Baghdadi, Al-Furqan media company, 14 May 2015, reproduced in: MEMRI, "In new audio speech, Islamic State (ISIS) leader Al-Baghdadi issues call to arms to all Muslims", 14 May 2015. 
event of that scale already designed, perceived and understood in the context of "global information village". More than a decade later, the originally and inherently regional Daesh phenomenon evolved at what could be described as the next stage of the increasingly dense glocal (global-local) information and political space and new opportunities for manipulating it. The widely available digital age tools facilitated the spread of popularity, appeal and attraction of Daesh far beyond the original core countries, across and well beyond the Middle East at large. These accumulated as a result of a combination of Daesh's military successes on the ground in two major armed conflicts, its growing territorial control, its extremely rigid religious-social norms and practices and far-reaching state-building ambitions, coupled with ultra-modern outreach and propaganda appeal and techniques. This fell at fertile ground at the time when mixed outcomes of the "Arab Spring" increased disillusion and disappointment with its goals - and methods - among some segments of Muslim societies in this and other parts of the world and in Muslim diaspora.

The growing importance of the region-based Daesh for the "global jihad" movement manifested itself in two main ways.

First, the influx of foreign jihadist fighters into Syria and Iraq intensified, with many of them, especially from the West, sharing and promoting a distinctively universalist agenda. Foreign jihadists had been present at the Iraqi front for over a decade (and comprised 4-10\% of Daesh's early predecessor "al-Qaeda in Iraq"). ${ }^{33}$ They had also fought on the side of the radical armed opposition in Syria since the early 2010s, especially in the ranks of groups such as mostly Syria-based and explicitly jihadist "Jabhat an-Nusrah" or in affiliated formations, such as "Jaish al-Muhajireen val'Ansar" ("army of migrants and followers"), well before "Islamic State of Iraq" (ISI) moved across the border from Iraq. However, the ISI expansion into Syria, its following rise as Daesh, its very self-generating/bottomup appeal coupled with robust army-style military capacity, higher resolve to use demonstratively extreme violence, greater ambitions and more thorough practices regarding the imposition of "Islamic order", and effective outbidding vis-a-vis local rivals, not only shifted the main inflows towards Daesh (with many foreign fighters already in the area simply shifting loyalties in its favor), but also led to a major increase in the overall numbers of newcomers. While the overall numbers, proportion and national composition of foreign fighters have been changing dynamically, two things became increasingly clear even at the pre-"Caliphate" stage of the Daesh evolution. First, while its army-style combat potential and military success were, to a significant extent, attributed to the presence of the Iraqi exBaathist professional security and military cadre, including at the top Daesh command level (possibly comprising up to a third of Al-Baghdadi's deputies in late 2014), foreign jihadists appeared to have been playing a disproportionately large role in atrocities against civilians, including beheadings. Second, it is the

33 Cf. Baker / Hamilton 2006. 
influx of foreign jihadist fighters, with their broader, more universalist agenda, that provided the region-based ISIS/L its first practical link to a truly globalized agenda.

Second, it is at this stage (e.g. well after the "Islamic State of Iraq" had expanded to Syria, become the lead jihadist force there and the main center of gravity for incoming jihadist flows from abroad, at the expense of local jihadist rivals such as "Jabhat an-Nusrah", and upgraded itself to "Islamic State of Iraq and ash-Sham"), not before, that the collision and competition with al-Qaeda started to become an issue. Even that collision, as noted above, did not initially emerge as some theoretical/theological exchange at an internet jihadist portal or elsewhere - it was preceded and catalyzed by Daesh's far more earthly competition with "Jabhat-an-Nusrah" on the ground in Syria and the decision by alQaeda's ideological leadership (embodied by Ayman az-Zawahiri) to side with the latter. ${ }^{34}$

Against this background, the significance and centrality of the formal declaration of the Caliphate on 29 June $2014^{35}$ (and of the Daesh leader Abu Bakr alBaghdadi as a "caliph") could not be overestimated. While hardly a radical threshold - rather, a product and fixation of a longer-term trend, the invocation of the "Islamic caliphate" as an ideological-religious construction and an experiment in its literal implementation could be seen precisely as a way to reconcile the inherently, essentially regional nature of the Daesh phenomenon (resulting from years of gradual bottom-up regionalization) with its growing importance and increasingly central role for the "global jihad" movement. This central role and global appeal - a long way from what first emerged years ago as a radical core of the Iraqi Sunni resistance - was a cross-cutting theme of al-Baghdadi's first speech as self-declared "caliph" on 1 July 2014,

O Muslims everywhere... raise your head high, for today - by Allah's grace - you have a state and khilāfah, which will return your dignity, might, rights, and leadership. It is a state where the Arab and non-Arab, the white man and black man, the easterner and westerner are all brothers. It is a khilāfah that gathered the Caucasian, Indian, Chinese, Shāmī, Iraqi, Yemeni, Egyptian, Maghribī (North African), American, French, German, and Australian... Therefore, rush O Muslims to your state... a state for all Muslims... Syria is not for the Syrians, and Iraq is not for the Iraqis. The earth is Allah's. ${ }^{36}$

"Caliphate" has become the main form and Daesh's take on the global jihad. With the "Caliphate" announced and in place on its physical territorial base in Iraq and Syria, regional drivers and "global jihad" ideology become not only reconciled, but also mutually reinforcing. The critical importance of holding and expanding

34 For more details, see Bayoumi / Harding 2014; Simonelli 2014.

35 See al-Adnani, "This is the Promise of Allah", op. cit. (note 22).

36 Amirul Mu'Minin Abu Bakr al-Husayni al-Qurashi al-Baghdadi 2015, p. 5. 
actual territorial control as a base for the "Islamic state", the need to be regionally-based in a physical sense, should be particularly stressed as an essential, sine qua non condition for declaring a caliphate even in the mainstream Islamic traditions (something that al-Qaeda, for instance, lacked in principle).

In practice, Abu Bakr al-Baghdadi's formal declaration of himself as the first "Caliph" in a thousand years reinforced Daesh's integration into and lead role in "global jihad" by (a) catalyzing an even more intense inflow of fighters, $(b)$ stimulating a wave of allegiance pledges to "Caliphate" from radical Islamist groups of all sizes and types at levels from local to regional and across regional contexts and $(c)$ formally launching its own major transnational migration/settler project.

(a) Direct pursuit and declaration of the "Caliphate", supported by military advances and territorial control in a key Muslim region, reinforced its outreach and appeal well beyond the core area of Iraq and Syria and made Daesh a magnet for the largest flow of foreign jihadist fighters ever. If, before the declaration of the "Caliphate", they numbered approximately 12000, still mostly in Syria, by the end of 2015, the overall numbers could be anywhere between 27000 and $31000^{37}$ (that appeared to be the peak number, as foreign fighters started to leave the area and the inflow of newcomers declined since air strikes supported by ground operations by region-based anti-Daesh forces intensified in late 2015-2016). Still, the estimated peak numbers considerably exceeded the scale of flows of foreign fighters during anti-Soviet jihad in Afghanistan. ${ }^{38}$ While militants from various active local fronts, both from elsewhere in the Middle East (the origin of the majority of foreign fighters) and from areas of low-intensity, Islamist-separatist conflicts on the periphery of Muslim-minority states of Asia and Eurasia, have been in high demand on the ground, in the battlefield, the role of the influx of jihadists from the West (even as they comprised between a fifth and a quarter of all foreign fighters) was indispensable as a link to "global jihad", in view of their generally more explicitly globalist agenda and universalist outlook.

(b) A parallel phenomenon of a parade of pledges of allegiance or loyalty to Daesh among the more locally based violent Islamist actors around the world could, in the more mundane sense, be partly explained by the former's appeal as a major politico-military and propaganda success story. These have been pledges not just in the name of an ideological current and symbolic figure or entity claiming to advance towards "caliphate" to be acquired in some distant future (as had been the case with local pledges of loyalty to "extraterritorial" Bin Laden and al-Qaeda in the 2000s), but to the "the Islamic state" here and now. The attraction of the "Caliphate", however, also has a purely religious/

37 Cf. Foreign Fighters: An Updated Assessment of the Flow of Foreign Fighters in Syra and Iraq, The Soufan Group report, December 2015.

38 Cf. Neumann 2015a. 
ideological explanation. Once established, caliphate activates a religious obligation for all righteous Muslims - on condition that they take its new "edition" seriously - to pledge loyalty. This is not to mention that it also activates a large portion of Sharia that can only be exercised by and under the Caliphate (which also partly explains some of the Daesh repressive "law enforcement" and social practices against "apostates", prisoners, slaves etc.).

(c) Finally, Daesh has also become a nascent transnational migration/settler project. One particular aspect, specific to Daesh as a quasi-state and an experiment in Islamist state-building, is the emphasis that its propaganda and ideology have placed upon marketing the "Caliphate" in the Iraq-Syria context as a final destination and a physical, rather than imagined, "promised land" for disenchanted Muslims from anywhere in the world. In al-Baghdadi's words: "O Muslims everywhere, whoever is capable of performing hijrah (emigration) to the Islamic State, then let him do so, because hijrah to the land of Islam is obligatory" ${ }^{39}$ Daesh's broader message was not just for the militants to fight, but also for civilians, including the fighters' family members, certain categories of professionals, as well as women and families with kids and other "right Muslims" to come and populate areas under their control (to live, work, provide administrative and technical skills, ensure logistical support for the war effort, do business, have kids). This often took the form of specific "targeted calls" for certain categories of newcomers: e.g., the July 2014 "special call" was "to the scholars, 'fuqahā' (experts in Islamic jurisprudence), and callers, especially the judges, as well as people with military, administrative, and service expertise, and medical doctors and engineers of all different specializations and fields" ${ }^{\prime 40}$; there were also repeated calls for professionals, as well as specifically for women and families to arrive. Paraphrasing a classic from a different cultural tradition, "Caliphate must be peopled". In sum, what made Daesh a qualitatively new phenomenon was also its potential - not yet realized even in half - to become a major ideologically-driven migration/settler movement and project in the Middle East (based on a radical Islamist ideology, value and governance system).

In combination, these three drivers helped create a centrifugal system, with the physical Caliphate in Syria and Iraq at its core, reinforced by inflows of foreign fighters from and beyond the Middle East, complemented by some flow of Muslim settlers, and extending to many more localized armed Islamist groups, cells and movements in different contexts via the "parade of pledges of loyalty" to Daesh.

Ironically, the Caliphate factor as the Daesh main "portal" to "global jihad" as an ideology and a movement is not only its main ideological/religious strength and

\footnotetext{
39 Amirul Mu'Minin Abu Bakr al-Husayni al-Qurashi al-Baghdadi 2015, p. 5.

40 Ibid., see also Dabiq, no. 2 and 3.
} 
link to global jihad, but also its biggest vulnerability. Once having declared a "Caliphate", to remain legitimate Daesh now becomes dependent on retaining and expanding territorial control in a certain region (not to mention that this in turn requires some top-down governance/administrative/military structure depriving the movement of an organizational advantages of flatter underground networks). This dependence, driven by the movement's religious ideology, reinforces the imperative to stick to the territory under Daesh control at any cost. This, however, also means that if they are prevented from expanding and holding to a physical territory and even deprived of a significant territorial control - this would not only diminish or neutralize their physical capacity to fight and engage in other forms of violence, but, more importantly, can seriously, if not decisively, undermine their ideological legitimacy in and beyond the region.

\section{Conclusion}

The explanation of the Daesh phenomenon has to start with the concrete region and at the regional level, not at the level of "global jihad" as a universalist ideological-religious movement. All contextual specifics notwithstanding, through the process of its evolution from "Islamic state in Iraq" into the selfproclaimed "Caliphate" with a territorial base in good half of Iraq and Syria, Daesh shared important similarities with several other major region-based jihadist actors. These could be summed up as the shared "bottom-up regionalization" dynamics.

What turned this regionally-based movement into the new cutting edge of "global jihad" as a movement and ideology?

One way to explain that suggested in this article is to see Daesh as a cumulative result of the interaction/merger of three major, cutting-edge trends in the evolution of transnational violent Islamism-jihadism in the early $21^{\text {st }}$ century.

(a) The first trend is the bottom-up "regionalization" process of violent Islamist movements briefly described above. While it can be traced in several Muslimpopulated regions, in the Middle Eastern context, it has been spurred and gravely aggravated by two of the world's three most intense, deadly and heavily transnationalized armed conflicts of the past decade and a half (in Iraq after 2003 and in Syria since 2011), state failure and disfunctionality, deep internal sectarian divisions, amplified by meddling by regional powers' and other regional sectarian forces, and the ideological/religious counterreaction to the "Arab spring" of the early 2010s.

(b) The second trend has developed in parallel, largely manifested itself in other regions and followed the opposite, decentralization direction. This refers to what could be called network fragmentation of "global jihad" movement - the emergence of small, autonomous, self-generating homegrown jihadist cells, often linked to the "movement" and to each other primarily or solely by the 
"global jihad" ideology, but seeing themselves as network agents and planning and undertaking militant-terrorist activity, at home or abroad, as parts of a global network. The sine qua non condition and the main "glue" for such network fragmentation could only be a universalist ideology of a radically anti-system type (at present, this role at the global level is played by religiousextremist ideology of "global jihad"). While such fragmented cells could be found in many countries, the ones with the most universalist outlook and agenda are actually to be found among the homegrown, but transnationally inspired jihadist cells and followers in the West and the "global North". While previously inspired primarily by al-Qaeda-style Salafist-jihadist vision (and more or less confirming to jihadist doctrines such as Abu as-Suri's concept of "jihad by individual cells"), ${ }^{41}$ in the mid-2010s, the main cutting edge and center of gravity for this type of cell and individual mobilization in ideological, symbolic and organizational terms has effectively been overtaken by Daesh and its self-established "Caliphate" as the most desired destination.

(c) The third trend has been the activation and intensification of intra- and crossregional transnational jihadist "migration flows" from predominantly Muslim countries and regions or those with significant and compact Muslim minorities (often from areas of active local armed conflicts of varying intensity), as well as from other regions (including individual and cells from fragmented networks in the West, or, more broadly, the developed world, or the "global North"). These flows are an upgrade from, and are no longer confined to, the more traditional circulation of more or less professionalized militants from one jihadist front to another. These flows are of the more multiple and diverse origin than even before and display a wide contextual variety of, borrowing from the physics terminology, the process "from activation to migration". At the same time, however, these militant "migrations" are increasingly targeted, pointed at, directed towards, and accumulated in three-five larger "centers of gravity" that correspond to the areas of the world's most intense and lethal regional armed conflicts that disproportionately account for the lion's share of both combat and terrorist activity in the world.

These three trends - (a) bottom-up regionalization, $(b)$ network fragmentation and $(c)$ intensifying and more concentrated transnational "targeted migrations" of jihadist militants - may be deeply rooted in different socio-political contexts and driven, enabled and facilitated by different sets and levels of causes and conditions. While inter-related, these trends are distinct, develop in parallel to one another, and only partially overlap. However, it is precisely in the space where they overlap - at the interface of all three - that we have got the Daesh phenomenon as we know it.

41 Cf. Al-Suri Abu Mus-ab 2004, pp. 1367 f. 


\section{References}

Abu Muhammad al-Adnani al-Shami: "This is the Promise of Allah", Al-I'tisam Media Foundation Twitter account, 29 June 2014 [account suspended by Twitter].

Abu Muhammad al-Adnani: "Indeed Your Lord Is Ever Watchful", in: pietervanostaeyen (blog), 22 September 2014.

Al-Suri, Abu Mus-ab: "The Call to Global Islamic Resistance”, CENTRA Technology, Inc., trans. from Arabic. DCIA Counterterrorism Center, Office of Terrorism Analysis, 2004.

Amirul Mu'Minin Abu Bakr al-Husayni al-Qurashi al-Baghdadi: "A Message to the Mujahidin and the Muslim Ummah in the Month of Ramadan", in: AlHayat Media Center, 1 July 2015, available at: http://www.gatestoneinstitute.org/documents/bagh dadi-caliph.pdf [02.05.2016].

Atwan, Abdel Bari: Islamic State: the Digital Caliphate. London 2015.

Azzam, Abdullah: "Defence of the Muslim Lands: The First Obligation after Iman, transl. from Arabic", in: Religioscope, February 2002.

Baker, James / Hamilton, Lee: The Iraq Study Group Report. Washington D.C. 2006.

Bayoumi, Alaa / Harding, Leah: "Mapping Iraq's fighting groups", in: Al-Jazeera, 27 June 2014.

Carmon, Y. et al.: "Understanding Abu Bakr Al-Baghdadi And The Phenomenon Of The Islamic Caliphate State", in: MEMRI Inquiry \& Analysis Series Report no. 1117, 14 September 2014, available at: http://www.memri.org/report/en/0/0/0/0/0/0/8147. htm [02.05.2016].

De Montclos, Marc-Antoine: Boko Haram: Islamism, Politics, Security and the State in Nigeria. Leiden 2014a.

De Montclos, Marc-Antoine: Nigeria's Interminable Insurgency? Addressing the Boko Haram Crisis, Chatham House Research Paper. London 2014b.

Gibbons-Neff, Thomas: "Number of foreign fighters entering Iraq and Syria drops by 90 percent, Pentagon says", in: Washington Post, 26 April 2016.

Gunaratna, Rohan: Inside Al Qaeda: Global Network of Terror. New York 2002.

Haddad, Fanar: "Shia-Centered State-Building and Sunni Rejection in Post-2003 Iraq", in: CEIP (7) January 2016, available at: http://carnegieendowment.org/2016/01/07/ shia-centric-state-building-and-sunni-rejection-in-post-2003-iraq/is5w [02.05.2016].

Haddad, Fanar: Sectarianism in Iraq: Antagonistic Visions of Unity. London / New York 2011.

Haykel, Bernard: "ISIS: a Primer”, in: Princeton Alumni Weekly, 3 June 2015.

Institute for Economics and Peace: Global Terrorism Index 2015: Measuring and Understanding the Impact of Terrorism (Sydney: Institute for Economics and Peace, 2015), available at: http://www.visionofhumanity.org/\#/page/our-gti-findings [02.05.2016].

Mansour, Renad: "The Sunni Predicament in Iraq", in: Carnegie Middle East Center Brief, 3 March 2016, available at: http://carnegie-mec.org/2016/03/03/sunni-predica ment-in-iraq/iusn [02.05.2016].

Marchal, Roland: The Rise of a Jihadi Movement in a Country at War: Harakat al Shabaab al Mujahiddin in Somalia, Centre de Recherches Internacionales (CERI), Research Paper. Paris 2011. 
Neumann, Peter: "Foreign Fighter Total in Syria/Iraq Now Exceeds 20,000; Surpasses Afghanistan Conflict in the 1980s", in: ICSR Insight, 26 January 2015a, available at: http://icsr.info/2015/01/foreign-fighter-total-syriairaq-now-exceeds-20000-surpassesafghanistan-conflict-1980s/ [02.05.2016].

Neumann, Peter: The New Jihadism: A Global Snapshot. London: International Centre for the Study of Radicalisation and Political Violence (ICSR), King's College, University of London, 2015b.

McFate, Jessica Lewis / Denaburg, Rob / Forrest, Caitlin: "Afghanistan Threat Assessment: the Taliban and ISIS", in: Institute for the Study of War (ISW) Backgrounder, 10 December 2015.

Qutb, Sayyid: Milestones. Cedar Rapids, Iowa 1980.

Rollins, John et al.: Al Qaeda and Affiliates: Historical Perspective, Global Presence, and Implications for U.S. Policy, CRS Report for Congress no. R41070. Washington D.C 2011a.

Rollins, John: Osama Bin Laden's Death: Implications and Considerations, CRS Report for Congress no. R41809. Washington D.C. 2011b.

Rubin, Barnett: Afghanistan from the Cold War through the War on Terror. Oxford 2015.

Ruttig, Thomas: “Afghan Taliban Contain Islamic States' Regional Reach”, in: Oxford Analytica Daily Brief, November 2015.

Simonelli, Corina: "The Evolution of the Islamic State of Iraq and the Levant (ISIL): Relationships 2004-2014", in: National Consortium for the Study of Terrorism and Responses to Terrorism (START) Fact Sheet, June 2014.

Stanford University: "Jabhat al-Nusra", in: The Mapping Militants project, Stanford University, Updated 1 Oct. 2015, available at: https://web.stanford.edu/group/map pingmilitants/cgi-bin/groups/view/493 [02.05.2016].

Stepanova, Ekaterina: "North Caucasus - a Wall Against or a Bridge for 'Islamic States'?", in: Russian International Affairs Council (RIAC) Analysis, 3 July 2015, available at: russiancouncil.ru/en/inner/?id_4=6269\&active_id_11=66\#top-content.

The Middle East Media Research Institute (MEMRI): "In new audio speech, Islamic State (ISIS) leader Al-Baghdadi issues call to arms to all Muslims" (Transcript of an audio speech by Abu Bakr Al-Baghdadi, Al-Furqan media company), reproduced in: The Middle East Media Research Institute (MEMRI), 14 May 2015, available at: http://www.memrijttm.org/in-new-audio-speech-islamic-state-isis-leader-al-baghdadi-is sues-call-to-arms-to-all-muslims.html [02.05.2016].

The Middle East Media Research Institute (MEMRI): The Islamic State (IS) Establishes Itself In Iraq And Syria. MEMRI Inquiry and Analysis Series Report no. 1126, 22 October 2014, available at: http://www.memri.org/report/en/0/0/0/0/112/0/8188.htm [02.05.2016].

The Soufan Group: Foreign Fighters: An Updated Assessment of the Flow of Foreign Fighters in Syra and Iraq. The Soufan Group report, December 2015, available at: http://soufangroup.com/wp-content/uploads/2015/12/TSG_ForeignFightersUpdate3. pdf.

The White House: National Strategy for Counterterrorism (Washington D.C.: The White House, 2011), available at: https://www.whitehouse.gov/blog/2011/06/29/nationalstrategy-counterterrorism [02.05.2016].

Weber, Max: The Protestant Ethic and the Spirit of Capitalism. London / New York 2005. 
Weber, Max: The Sociology of Religion. Boston 1993.

"Who are ISIS's top 20 Leaders?", in: Al-Arabiya, 19 September 2014.

Williams, Rhys: "Religion as political resource: culture or ideology", in: Journal for the Scientific Study of Religion (35/4) 1996, pp. 368-378.

Wood, Graeme: "What ISIS really wants", in: The Atlantic, March 2015, available at: http://www.theatlantic.com/magazine/archive/2015/03/what-isis-really-wants/384980/ [02.05.2016]. 